metabolites which are either water-soluble themselves or capable of combining with the pyridine nucleotides. However, DPN or TPN could not replace DPNH or TPNH in the reaction in the presence of added hydrogen peroxide, and this finding deserves further investigation. A number of other compounds having features in common with the nucleotides (see footnote to Table 1) were tested but none had any effect.

Only when water-soluble products were formed could compounds other than the added oestrogen be detected in the ether extracts and these were all found to be more polar than oestrone and, with the exception of one compound, more polar than ostradiol-17ß. Very little, if any, of this last steroid was formed.

Similar incubations with a lyophilized preparation $(5 \mathrm{mg})$ of oestrogen-stimulated rat uteri, which in the presence of manganese and 2,4-dichlorophenol was shown to have high DPNH oxidase activity, did not result in the formation of water-soluble products from œstrone. In addition, this material did not give a positive reaction ${ }^{6}$ with guaiacol, which suggests that the oxidase and peroxidase activities of ostrogen-stimulated rat uteri may be separate in contrast to horseradish peroxidase where both functions appear to be intimately connected. Hollander and Stephens? found that these two enzymatic activities were lost from uterine homogenates at different rates on storage, but their results indicate that the oxidase was more labile than the peroxidase.

Finally, it should be mentioned that the results with horseradish peroxidase are not in conflict with those obtained by Williams-Ashman et al. ${ }^{8}$, who managed to recover virtually all their added œestradiol unchanged after incubation under similar conditions, since their experimonts were of relatively short duration.

We thank Drs. V. P. and N. Hollander for a gift of rat uterine DPNH oxidase and Prof. R. L. Noble and the National Cancer Institute of Canada for their interest and support of this work.

Cancer Research Centre.

University of British Columbia, Vancouver.

'Lucas, F. V., Neufeld, H. A., Utterback, J. C., Martin, A. P., and Stotz, E., J. Biol. Chem., 214,775 (1955).

${ }^{2}$ Neufeld, H. A., Levay, A. N., Lucas, F. V., Martin, A. P.. and Stotz. E. J. Biol. Chem.,233, 209 (1958).

3 Jellinek, P. H., and Irwin, L., Nature, 192, 660 (1961).

‘.Jellinck, P. H., and Irwin, I., Canad. J. Biochem. and Physiol., 40, 459 (1962)

'Jellinck, P. H., Biochem. J., 71, 665 (1959).

6 Jermyn, M. A., Nuture, 169, 488 (1952).

${ }^{7}$ Hollander, Y. P., and Stephens, M. L., J. Biol. Chem., 234, 1901 (1959).

${ }^{8}$ Williams-Ashman, H. G.. Cassman, M., and Klavins, M., Nature, 184, $427(1959)$.

\section{Interference by Ammonium Sulphate with the Estimation of Proteins by the Biuret Reaction}

THE procedure of Gornall, Bardawill and David ${ }^{1}$ is widely used for the estimation of proteins, the only frequent modification being adjustment of the volumes to permit mixing of reagents and reading of the extinction directly in the cells of a spectrophotometer. Gornall, Bardawill and David' state that 'ammonium ion is a disturbing factor in the biuret reaction', but provide no quantitative data. Some information on the interference has been provided by Henry, Sobel and Berkman ${ }^{2}$; but these workers used two biuret reagents of different composition and instead of a pure protein used serum as a standard. The extent of the interference of ammonium ion with the biuret reaction does not appear to be widely known. Thus, Dixon and Webb ${ }^{3}$ claim that "few of the non-protein materials likely to be present affect the estimation, and it is particularly useful because it is insensitive to ammonium salts".
Crystalline egg albumin (Sigma Chemical Co., St. Louis 18, Mo.) was dissolved in $0.15 \mathrm{M}$ sodium chloride to a concentration of $10 \mathrm{mg} / \mathrm{ml}$. Biuret reagent was prepared according to Gornall, Bardawill and David ${ }^{1}$ Protein solution $(0.2 \mathrm{ml}$.$) , freshly filtered, saturated \left(20^{\circ}-22^{\circ}\right)$ ammonium sulphate and sufficient $0.15 \mathrm{M}$ sodium chloride to bring the volume to $1.5 \mathrm{ml}$. were mixed and $1.5 \mathrm{ml}$. biuret reagent was added. The mixtures stood for $30 \mathrm{~min}$ at $20-22^{\circ}$. The extinction at $540 \mathrm{~m} \mu$ was determined in a Shimadzu $Q R 50$ spectrophotometer, using a blank consisting of $1.5 \mathrm{ml} .0 .15 \mathrm{M}$ sodium chloride and $1.5 \mathrm{ml}$. biuret reagent. The extinction values for duplicate tests with constant protein content and varying final concentrations of ammonium sulphate are shown in Table 1.

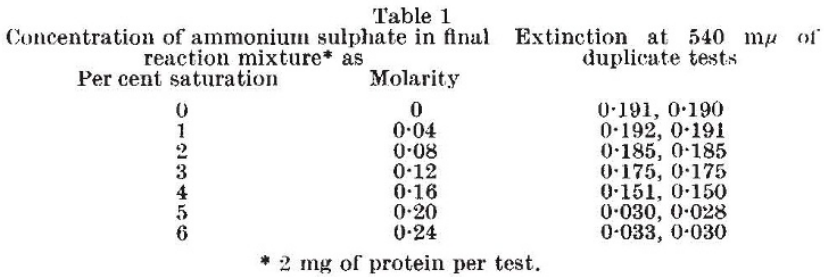

It is clear from the results in Table 1 that a concentration of $0.08 \mathrm{M}$ ammonium sulphate in the final reaction mixture already interferes appreciably with the recovery of protein, even though the level of protein selected for the tests was near the upper limit of the range in which extinction at $540 \mathrm{~m} \mu$ is linearly related to the concentration of protein.

This work was supported by the National Health and Medical Research Council, Canberra.

\section{P. G. Stanley}

Wellcome Laboratory of the Unit of Clinical Investigation, Royal North Shore Hospital of Sydney, Crow's Nest, New South Wales.

\footnotetext{
Gornall, A. G., Bardawill, C. J., and David, M. M., J. Biol. Chem., 177, 751 (1949).

${ }^{2}$ Henry, R. J., Sobel, C., and Berkman, S., Anal. Chem., 29, 1491 (1957).

3 Dixon, M., and Webb, E. C., in Enzymes. 39 (Longmans, Green and Co., London. New York, Toronto, 1957).
}

\section{Composition of Normal and Pathological Cutaneous Elastin}

ELASTIN, a fibrous protein invariably associated with collagen ${ }^{1,2}$, has been quantitatively measured in a variety of mammalian tissues ${ }^{3,4}$. The amino-acid composition of elastin prepared from various animal sources including aorta ${ }^{5}$, lung ${ }^{6}$ and ligamentum nuch $\circledast^{7}$ has been reported and the elastin content of human dermis has been determined $^{8,9}$. The purpose of this work was to determine the amino-acid composition of human dermal elastin and compare it with that of the elastin-like proteins found in increased amounts in chronically sun-damaged skin (actinic elastosis) and pseudoxanthoma elasticum ${ }^{8}$.

Human skin was obtained at necropsy from two Caucasian adults. Actinic elastotic skin was removed under local anæsthesia from the forearm of two volunteers with a Brown dermatome (obtained from Dr. C. C. Tindall, Kissimmee, Florida). Pseudoxanthoma elasticum skin was obtained from a 46-year-old White female who died of a cerebral vascular accident with progressivo deterioration (obtained from Dr. S. Polt, Duke University Medical Center). All hair was carefully romoved by shaving and subcutanoous fat trimmed away. Skin specimens were frozen in liquid nitrogen, ground in a Wiley mill, and extracted three times with $0 \cdot 1 \mathrm{~N}$ sodium hydroxide in boiling water bath for $15 \mathrm{~min}^{3}$. Between the first and second extractions the skin specimens were ground in a glass homogenizer. The suspensions were centrifuged at $20,000 \mathrm{~g}$ and the residues air-dried on filter paper after washing with acetone and ether. Aliquots wero desiccated in a vacuum oven for $3 \mathrm{~h}$ 